\title{
KANDUNGAN KLOROFIL BERBAGAI J ENIS DAUN TANAMAN DAN CU-TURUNAN KLOROFIL SERTA KARAKTERISTIK FISIKO-KIMIANYA
}

\author{
(Chlorophyll Level of Various Geen Leaves and \\ Copper-chlorophyll derivatives and its Charaterization) \\ Nurdin $^{1}$, Clara M. Kusharto ${ }^{2 *}$, Ikeu Tanziha ${ }^{2}$, dan M. J anuwati ${ }^{3}$ \\ 1 Program Studi Kimia, Fakultas Keguruan dan IImu Pendidikan, Universitas Tadulako, Palu. \\ ${ }^{2 *}$ Alamat Korespondensi: Departemen Gizi Masyarakat, Fakultas Ekologi Manusia, Institut Pertanian \\ Bogor, Bogor 16680. Telp: 0251-8621258; Fax: 0251-8622276; Email: kcl@indo.net.id \\ 2 Departemen Gizi Masyarakat, Fakultas Ekologi Manusia, Institut Pertanian Bogor, Bogor 16680 \\ 3 Balai Penelitian Tanaman Obat dan Aromatik, Departemen Pertanian, Cimanggu, Bogor
}

\begin{abstract}
ABST RACT
The chlorophyll is well known as natural antioxidant which is commonly high level in some geen leafy and has potential biological effect for a good health and has been proved has antioxidant and antimutagenic activity. In fact, a high content of chlorophyll is available in nature but in contrast its found commercially in Indonesia as imported product with a high price. The objectives of this study were to determine of chlorophyll level of various leaves (Premna oblongifolia Merr., Saurpus androgynus Merr. Centella asiatica, and Morus alba L), to produce copper-chlorophyll derivative powder, and to observe its physico-chemical properties. The research showed that cincau leaf had higher level of chlorophyll than other leaves, meanwhile cincau leaf used as material of copperchlorophyll derivative. Cincau leaves chlorophyll extract solution with $\mathrm{Cu}^{2+} 100 \mathrm{mg} /$ l level produce the cincau copper-chlorophyll derivative powder with highest $\mathrm{pH}$, solubility, and geenness compare to other copper levels. The cincau copper-derivate chlorophyll powder contained chlorophyll $3986 \mathrm{mg} / \mathrm{kg}, \beta$-carotene $33.8 \mathrm{mg} / \mathrm{kg}$, and contained alkaloid, saponin, tanin, steroid, and glycoside.
\end{abstract}

Keywords: chlorophyll, Premna oblongifolia Merr., Saurpus androgynus Merr., Centella asiatica, Morus alba L., copper-chlorophyll derivative

\section{PENDAHULUAN}

Indonesia sebagai negara tropis memiliki kekayaan alam berbagai jenis tumbuhan yang mempunyai kandungan bahan aktif tertentu yang bermanfaat untuk kesehatan. Terdapat kurang lebih dari 7000 spesies tumbuhan (90\% dari spesies tumbuhan Asia) diketahui berkhasiat sebagai obat (BPOM, 2001). Sebagian besar tumbuhan ini (hampir $80 \%$ sudah lama dipergunakan oleh penduduk lokal sebagai obatobatan tradisional, namun belum diusahakan secara optimal untuk pengembangan obat yang memberikan nilai ekonomis dan dapat meningkatkan pendapatan petani tanaman itu sendiri.

Daun tumbuhan mengandung berbagai zat gizi maupun non-gizi (metabolit sekunder), seperti vitamin, mineral, serat pangan, betakaroten, dan klorofil. Konsumsi bahan pangan nabati (sayuran atau dedaunan) sering dikaitkan dengan menurunnya risiko menderita penyakit degeneratif, khususnya penyakit jantung koroner (PJK). Hal ini tidak terlepas dari kandungan senyawa bioaktif dari pangan nabati tersebut. Senyawa antioksidan alami yang diduga banyak terdapat dalam sayuran atau dedaunan hijau adalah klorofil. Beberapa hasil penelitian menunjukkan bahwa klorofil dan turunannya memiliki kemampuan sebagai antioksidan dan antimutagenik (Marquez et al., 2005, Ferruzzi et al., 2006).

Ketersediaan klorofil yang tinggi di alam serta khasiat biologis yang dimilikinya, menjadi peluang untuk dikembangkan sebagai bahan suplemen pangan atau pangan fungsional (Prangdimurti, 2007). Sementara itu suplemen pangan berbasis klorofil yang beredar di Indonesia hampir semuanya merupakan produk impor dan memiliki harga jual yang cukup tinggi.

Penelitian tentang absorpsi dan metabolisme klorofil masih terbatas. Hal ini berhubungan dengan sifat klorofil alami yang mudah terdegadasi oleh asam, panas, cahaya, dan oksigen (Goss, 1991; Kotani et al., 1999). 
Klorofil dan turunannya yang mengikat logam mempunyai kapasitas antioksidan dan bioavailabilitas yang berbeda. Cu-klorofilin sebagai salah turunan klorofil mempunyai aktivitas antioksidan yang lebih tinggi dibandingkan klorofil alami (Marquez et al., 2005).

Pengikatan logam oleh klorofil bertujuan untuk meningkatkan kestabilan ekstrak klorofil yang dihasilkan (von Elbe et al., 1986; Canjura et al., 1999). Salah satu turunan klorofil yang masih terbatas dipelajari efeknya bagi pencegahan penyakit degeneratif adalah turunan klorofil yang mengikat logam tembaga (Cu). Tembaga merupakan salah satu mikromineral essensial selain I, $\mathrm{Zn}$, Se, Mo, dan $\mathrm{Cr}$, mempunyai tingkat stabilitas kompleks logam dengan porfirin yang lebih tinggi. Cheng et al. (1982), menyatakan tingkat stabilitas kompleks logam adalah berturut-turut sebagai berikut: $\mathrm{Pt}>\mathrm{Pd}>\mathrm{Ni}>\mathrm{Co}>\mathrm{Cu}>\mathrm{Fe}>\mathrm{Zn}>\mathrm{Mn}>\mathrm{Mg}>\mathrm{Cd}>\mathrm{Sn}>\mathrm{Hg}>\mathrm{Pb}>$ Ba.

Pada penelitian ini ditentukan kandungan klorofil berbagai daun (cincau, katuk, murbei, dan pegagan). Daun yang mempunyai kadar klorofil tertinggi, dibuat menjadi bubuk Cu-turunan klorofil menggunakan bahan pengisi dekstrin dan freeze dryer.

Penelitian ini bertujuan untuk (1) Menganalisis kadar klorofil dari berbagai jenis daun tanaman (daun cincau, daun pegagan, daun katuk, dan daun murbei), dan (2) Membuat sediaan bubuk ekstrak Cu-turunan klorofil dan mengamati karakteristiknya.

\section{METODE}

\section{Desain, Tempat, dan Waktu Penelitian}

Penelitian ini merupakan penelitian eksperimental yang dilaksanakan di Laboratorium Balittro Cimanggu Bogor. Penelitian dilaksanakan pada bulai Mei hingga Agustus 2008 dan didanai oleh Sekretariat Badan Litbang Pertanian Departemen Pertanian RI melalui Prog KKP3T dengan No. Kontrak: 723/ LB.620/I.1/3/ 2008.

\section{Bahan dan Alat}

Bahan-bahan yang digunakan adalah daun cincau, daun pegagan, daun katuk, dan daun murbei. Alat yang digunakan antara lain kertas saring Whatman No. 1 dan 42, erlenmeyer vakum, pompa vakum, pH meter, rotavapor, spektrofotometer, dan freeze dryer.
1. Penentuan kadar klorofil empat jenis daun tanaman (daun cincau, daun katuk, daun pegagan, dan daun murbei)

Metode penentuan konsentrasi klorofil dilakukan dengan metode International Rice Research Institute (IRRI) yang telah dimodifikasi oleh Balitbio Bogor (Alsuhendra, 2004). Sebanyak $0,1 \mathrm{~g}$ daun cincau hijau, daun pegagan, daun katuk, daun murbei, yang telah dirajang (ukuran sekitar $2 \mathrm{~mm}$ ), dimasukkan ke dalam tabung reaksi, kemudian ditambahkan aseton sebanyak $20 \mathrm{ml}$. Campuran tersebut dikocok secukupnya, lalu didiamkan selama $2 \times$ 24 jam. Ekstrak yang diperoleh dianalisis konsentrasi klorofil a maupun klorofil $b$-nya menggunakan spektrofotometer, masingmasing pada panjang gelombang 645 dan 663 $\mathrm{nm}$.

\section{Ekstraksi klorofil, penyiapan turunan klorofil, pembuatan kompleks Cu-turunan klorofil}

Ada 3 langkah yang dilakukan pada tahap ini, yaitu persiapan bahan ekstrak klorofil dan penyiapan turunan klorofil serta pembuatan kompleks Cu-turunan klorofil.

\section{a. Persiapan bahan}

Daun yang terpilih pada Tahap I (daun pegagan) dibersihkan dari berbagai kotoran, lalu dilap dengan tissu, selanjutnya dikeringanginkan. Daun tersebut lalu dipotong kecilkecil dengan gunting untuk memudahkan proses penghancuran.

\section{b. Ekstraksi klorofil}

Sebanyak \pm 50 g potongan daun terpilih dihancurkan dengan blender menggunakan 125 $\mathrm{ml}$ etanol 95\% selama 3 menit, secara terputus setiap 1 menit. Hancuran kemudian disaring dengan kain saring halus (60 mesh), lalu filtrat yang diperoleh disaring lagi dengan corong Buchner menggunakan kertas saring Whatman No.1 dan 42 secara berturut-turut. Penyaringan menggunakan pompa vakum. Residu dicuci dengan $75 \mathrm{ml}$ etanol 95\% kemudian disaring lagi dengan corong Buchner (Alsuhendra, 2004). Filtrat diambil sebagai ekstrak kasar klorofil. Semua proses dilakukan dalam kondisi terhindar dari cahaya.

c. Penyiapan turunan klorofil dan pembuatan kompleks Cu-klorofil

Pembentukan turunan klorofil (feofitin) dilakukan dengan mengasamkan klorofil yang telah diekstrak dengan menambahkan $\mathrm{HCl} 1 \mathrm{M}$ hingga pH larutan mencapai 5.0 (Alsuhendra, 2004). Kompleks Cu-turunan klorofil dibuat dengan cara menambahkan $180 \mathrm{ml}$ filtrat 
ekstrak yang mengandung $0,50,100$, dan 150 $\mathrm{mg} / \mathrm{l} \mathrm{Cu}{ }^{2+}$.

Ekstrak turunan klorofil yang telah ditambah $\mathrm{Cu}^{2+}$ dinaikkan pH-nya hingga 8.5 dengan menambahkan $\mathrm{NaOH} 1 \mathrm{M}$. Reaksi dilakukan di dalam labu tertutup selama 30 menit menggunakan magnetic stirrer (Alsuhendra, 2004).

Setelah reaksi berlangsung sempurna, campuran tersebut ditambahkan dekstrin 3\% Reaksi dilakukan selama 30 menit menggunakan magnetic stirrer. Kecepatan magnetic stirrer diatur pada skala 7. Setelah reaksi selesai, campuran dimasukkan dalam freezer $\left(-20^{\circ} \mathrm{C}\right)$ dan didiamkan selama semalam sebelum dikeringkan dengan pengering beku (freeze dryer). Setelah campuran kering, maka diperoleh bubuk Cu-turunan klorofil.

\section{Karakterisasi fisiko-kimia bubuk ekstrak Cu-turunan klorofil}

Bubuk Cu-turunan klorofil yang dipilih untuk dikarakterisasi lebih lanjut adalah yang mempunyai tingkat kelarutan tinggi, pH tinggi, dan tingkat warna hijau yang tinggi. Untuk mempelajari sifat fisik dari bubuk turunan $\mathrm{Cu}$ klorofil yang dihasilkan dilakukan uji proksimat, uj $\mathrm{i}$ fitokimia, dan $\beta$-karoten (metode HPLC).

\section{HASIL DAN PEMBAHASAN}

Sebelum penentuan jenis daun tanaman yang akan digunakan dalam pembuatan bubuk Cu-turunan klorofil, maka terlebih dahulu dilakukan screening konsentrasi klorofil dari berbagai daun tanaman, di antaranya cincau, katuk, murbei, dan pegagan. Hasil penentuan konsentrasi klorofil tersebut dapat dilihat pada Tabel 1.

Pada Tabel 1 tampak bahwa daun yang mempunyai kadar klorofil tertinggi adalah daun cincau dengan kadar $1708.8 \mathrm{mg} / \mathrm{kg}$. Berdasarkan hasil ini, maka daun cincau akan digunakan untuk proses penelitian selanjutnya, yaitu untuk pembuatan bubuk Cu-turunan klorofil.
Tabel 1. Konsentrasi Klorofil dari Berbagai Daun Tanaman

\begin{tabular}{lrrrr}
\hline \multirow{2}{*}{ Jenis Daun } & \multirow{2}{*}{$\begin{array}{c}\text { Berat } \\
(\mathbf{g})\end{array}$} & \multicolumn{3}{c}{ Konsentrasi Klorofil $\mathbf{( m g / k g )}$} \\
\cline { 3 - 5 } & & $\begin{array}{c}\mathbf{a}(\mathbf{6 4 5}) \\
\mathbf{n m})\end{array}$ & $\begin{array}{c}\mathbf{b}(\mathbf{6 6 3} \\
\mathbf{n m})\end{array}$ & \multicolumn{1}{c}{ Total } \\
\hline Pegagan & 0.2 & 612.5 & 219.0 & 831.5 \\
Katuk & 0.2 & 1136.6 & 372.5 & 1509.1 \\
Murbei & 0.2 & 651.7 & 192.5 & 844.2 \\
Cincau hijau & 0.2 & 1300.0 & 408.7 & 1708.8 \\
\hline
\end{tabular}

\section{Bubuk Cu-turunan klorofil Daun Cincau} (Premna oblongifolia Merr.)

Pembuatan bubuk Cu-turunan klorofil diawali dengan melakukan ekstraksi daun cincau hijau menggunakan etanol 95\% Etanol digunakan karena relatif aman dibanding pelarut lain (dietil eter, aseton, metanol, petroleum, dan eter). Pengekstrak etanol juga dapat memberikan nilai recovery yang tinggi, dan kemurnian klorofil (Bianca, 1993; Mahmud, 1994; Alsuhendra, 2004).

Pada pembuatan bubuk Cu-turunan klorofil menggunakan bahan pengisi dekstrin 3\% Tujuan penggunaan dekstrin ini adalah untuk mempersingkat waktu pengeringan dan menghasilkan performa produk yang relatif bagus. Hasil penelitian pendahuluan menunjukkan bahwa ekstrak $\mathrm{Cu}$-turunan klorofil yang dikeringkan tanpa menggunakan dekstrin, produknya lengket pada wadah (bubuk tidak terbentuk) dan warnanya hijau kehitam-hitaman. Hal ini berarti bahwa semakin kecil konsentrasi dekstrin (di bawah 3\%), performa produk relatif kurang optimal.

Alasan penambahan Cu pada ekstrak klorofil (turunan klorofil) adalah untuk mempertahankan kestabilan warna hijau klorofil dan meningkatkan kelarutan maupun $\mathrm{pH}$ dari produk bubuk yang dihasilkan. BPOM (2004) mensyaratkan konsumsi Cu perhari sebesar $3 \mathrm{mg} /$ hari. Syarat ini relatif lebih rendah dibanding upper limit (UL) dari Cu yaitu 10 mg/ hari.

\section{Karakteristik Fisiko-Kimia Bubuk Ekstrak Cu- turunan klorofil dari Berbagai Konsentrasi $\mathrm{Cu}$}

Bubuk ekstrak Cu-turunan klorofil mengandung tembaga yang kadarnya berbeda, yaitu masing-masing $0,50,100$, dan $150 \mathrm{mg} / \mathrm{l}$. Untuk menentukan bubuk ekstrak yang akan dipilih untuk bahan intervensi pada hewan coba (kelinci), maka dilakukan uji karakteristik fisiko-kimia utama antara lain: rendemen, $\mathrm{pH}$, kelarutan, dan warna. Khusus untuk uj i warna 
digunakan parameter antara lain: tingkat kecerahan atau whiteness (W), kehijauan atau geeness $(G)$, dan kekuningan atau yellowness (Y). Hasil uji pH dan kelarutan dapat dilihat pada Tabel 2 dan uji warna pada Tabel 3.

\section{Rendemen}

Ada 2 jenis rendemen yang dihitung, yaitu bubuk Cu-turunan klorofil tanpa menggunakan dekstrin dan dengan dekstrin. Rendemen bubuk klorofil tanpa penambahan dekstrin adalah sebanyak $5.8 \%$

Rendemen dihitung berdasarkan jumlah massa (g) bubuk Cu-turunan klorofil (mengandung dekstrin) yang diperoleh dibandingkan dengan berat daun cincau hijau yang digunakan untuk membuat ekstrak. Dari Tabel 2 tampak bahwa bubuk kontrol negatif ( $\mathrm{Cu} 0$ $\mathrm{mg} / \mathrm{l})$ memiliki rendemen yang paling rendah dibanding bubuk ekstrak lainnya. Produk yang ekstraknya mengandung Cu 150 mg/ I memiliki rendemen yang tertinggi, wa- laupun tidak berbeda nyata ( $p>0.05)$ dengan produk bubuk yang ekstraknya mengandung $\mathrm{Cu} 100$ ppm. Terjadinya perbedaan rendemen ini diduga karena adanya perbedaan kandungan $\mathrm{Cu}$ dari produk bubuk yang dihasilkan.
pH

pH menunjukkan tingkat keasaman suatu produk. pH akhir dari produk ekstrak $\mathrm{Cu}-$ turunan klorofil yang dihasilkan adalah 8.5. Pengukuran $\mathrm{pH}$ produk bubuk ekstrak $\mathrm{Cu}$ turunan klorofil dilakukan setelah pengeringan produk menggunakan freeze dryer. Pada Tabel 2 tampak bahwa produk dengan konsentrasi $\mathrm{Cu}$ 0 ppm memiliki pH paling rendah, dan berbeda nyata $(p<0.05)$ dengan produk lainnya.

Produk yang memiliki pH paling tinggi yaitu 7.64 adalah produk ekstrak yang mengandung Cu 100 ppm, sedangkan produk ekstrak dengan kandungan $\mathrm{Cu} 150$ ppm memiliki pH 7.28. Hal ini menunjukkan bahwa produk yang mengandung $\mathrm{Cu} 100$ ppm relatif lebih mampu menahan penurunan $\mathrm{pH}$ selama proses pengolahan (pengeringan). Penurunan $\mathrm{pH}$ dapat disebabkan karena suatu produk berinteraksi dengan $\mathrm{CO}_{2}$ yang ada di udara. Hasil yang diperoleh ini sesuai dengan pernyataan LaBorde dan von Elbe (1994) dalam Alsuhendra (2004), bahwa penambahan beberapa bahan yang bersifat alkali pada sayuran dapat mempertahankan warna hijau klorofil karena terjadinya kenaikan $\mathrm{pH}$, dimana pada pH tinggi, stabilitas klorofil juga relatif tinggi.

Tabel 2. Rata-rata Rendemen, pH, dan Kelarutan Bubuk Ekstrak Cu-turunan Klorofil

\begin{tabular}{cccc}
\hline $\begin{array}{c}\text { Bubuk dengan kadar Cu } \\
\text { (mg/l) }\end{array}$ & $\begin{array}{c}\text { Rendemen } \\
\text { (\%) }\end{array}$ & pH & $\begin{array}{c}\text { Kelarutan } \\
(\%)\end{array}$ \\
\hline 0 & $13.95 \pm 0.07^{\mathrm{a}}$ & $4.53 \pm 0.04^{\mathrm{a}}$ & $91.07 \pm 0.11^{\mathrm{a}}$ \\
50 & $14.10 \pm 0.14^{\mathrm{a}}$ & $7.53 \pm 0.09^{\mathrm{bc}}$ & $92.57 \pm 0.08^{\mathrm{b}}$ \\
100 & $14.20 \pm 0.14^{\mathrm{ab}}$ & $7.64 \pm 0.12^{\mathrm{c}}$ & $98.04 \pm 0.36^{\mathrm{c}}$ \\
150 & $14.45 \pm 0.07^{\mathrm{b}}$ & $7.28 \pm 0.15^{\mathrm{b}}$ & $98.26 \pm 0.59^{\mathrm{c}}$ \\
\hline
\end{tabular}

Angka dengan huruf yang sama (1 kolom) menunjukkan tidak berbeda nyata pada $a=0.05$

Tabel 3. Rata-rata Nilai Uji Warna Bubuk Ekstrak Cu-turunan Klorofil, Sebelum dan Sesudah Dipanaskan

\begin{tabular}{|c|c|c|c|c|c|c|}
\hline \multirow{3}{*}{$\begin{array}{c}\mathrm{Cu}^{2+} \\
(\mathrm{mg} / \mathrm{l})\end{array}$} & \multicolumn{6}{|c|}{ Nilai Uji Warna } \\
\hline & \multicolumn{3}{|c|}{ Sebelum dipanaskan } & \multicolumn{3}{|c|}{ Sesudah dipanaskan } \\
\hline & w & G & $\mathbf{Y}$ & w & $\mathbf{G}$ & $\mathbf{Y}$ \\
\hline 0 & $36.82 \pm 0.03^{d}$ & $-4.31 \pm 0.43^{c}$ & $12.47 \pm 0.27^{d}$ & $37.09 \pm 0.02^{d}$ & $-5.93 \pm 3.48^{\mathrm{a}}$ & $12.44 \pm 0.07^{d}$ \\
\hline 50 & $28.42 \pm 0.06^{\mathrm{a}}$ & $-5.99 \pm 0.04^{b}$ & $8.18 \pm 0.03^{\mathrm{a}}$ & $29.67 \pm 0.05^{\mathrm{a}}$ & $-5.86 \pm 0.02^{\mathrm{a}}$ & $8.75 \pm 0.02^{\mathrm{a}}$ \\
\hline 100 & $32.88 \pm 0.01^{c}$ & $-8.83 \pm 0.04^{\mathrm{a}}$ & $11.20 \pm 0.03^{c}$ & $33.05 \pm 0.04^{c}$ & $-7.74 \pm 0.03^{\mathrm{a}}$ & $11.04 \pm 0.00^{c}$ \\
\hline 150 & $32.12 \pm 0.01^{b}$ & $-8.44 \pm 0.04^{\mathrm{a}}$ & $10.61 \pm 0.04^{\mathrm{b}}$ & $32.39 \pm 0.01^{b}$ & $-7.55 \pm 0.05^{\mathrm{a}}$ & $10.21 \pm 0.06^{b}$ \\
\hline
\end{tabular}

Angka dengan huruf yang sama (1 kolom) menunjukkan tidak berbeda nyata pada $a=0,05$

$W=$ kecerahan (whiteness); $G$ = tingkat kehijauan (geeness) dengan tanda + berarti merah, dan - adalah hijau;

$Y=$ tingkat kekuningan (yellowness), dengan tanda + berarti kuning, dan - adalah biru 


\section{Kelarutan}

Kelarutan menunjukkan banyaknya bagian dari suatu produk yang dapat larut dalam suatu pelarut dengan volume tertentu. Pada Tabel 2 tampak bahwa kelarutan dalam air cenderung meningkat dengan bertambahnya konsentrasi $\mathrm{Cu}$ yaitu berkisar antara $91.07 \%$ dan $98.26 \%$ Hasil kelarutan produk ini relatif lebih tinggi dibanding hasil penelitian Alsuhendra (2004) yang menggunakan sistem pengering spray dryer untuk mengekstrak klorofil daun singkong dengan zat pengompleks Zn (100 ppm) yaitu antara $89.4 \%$ dan $90.7 \%$

Produk dengan penambahan $\mathrm{Cu} 0 \mathrm{ppm}$ memiliki kelarutan paling rendah yaitu $91.07 \%$ Rendahnya kelarutan ini diduga karena $\mathrm{Mg}^{2+}$ yang terlepas dalam sistem larutan konsentrasinya relatif rendah, sehingga kemampuan pengikatan molekul klorofil dari produk ini dengan dekstrin dan air menjadi turun, sedangkan produk dengan penambahan Cu 150 mg/l memiliki kelarutan paling tinggi, namun tidak berbeda nyata ( $p>0.05)$ dengan $\mathrm{Cu} 100 \mathrm{mg} / \mathrm{l}$. Tingginya kelarutan ini diduga karena banyaknya $\mathrm{Cu}$ yang tidak terikat (terlepas) pada cincin tetrapirol, sehingga dalam larutan berubah menjadi $\mathrm{Cu}^{2+}$ yang mempunyai kelarutan tinggi.

\section{Warna}

Uji warna ini dilakukan untuk menentukan tingkat kecerahan (whiteness), kehijauan (geeness), dan tingkat kekuningan (yellowness) dari produk bubuk Cu-turunan klorofil menggunakan kromameter. Uji warna dilakukan sebelum dan sesudah pemanasan pada suhu $105^{\circ} \mathrm{C}$. Datanya disaj ikan pada Tabel 3.

\section{(1). Tingkat Kecerahan (W)}

Pada Tabel 3 tampak produk bubuk dengan konsentrasi Cu 0 ppm mempunyai tingkat kecerahan yang tertinggi yaitu sebesar 36.82, namun tingkat kehijauannya paling rendah di antara semua produk bubuk. Tingginya tingkat kecerahan bubuk yang mengandung $\mathrm{Cu} O \mathrm{ppm}$ karena memang awalnya produk tersebut berwarna coklat-terang. Tingkat kecerahan tertinggi berikutnya adalah produk bubuk dengan konsentrasi Cu 100 ppm. Pada Tabel tersebut juga tampak bahwa semua produk bubuk dengan berbagai konsentrasi $\mathrm{Cu}$ mengalami kenaikan tingkat kecerahan setelah dipanaskan pada suhu $105^{\circ} \mathrm{C}$, dan berbeda nyata di antara semua perlakuan. Hal ini dapat disebabkan karena terjadinya penguapan pelarut.

\section{(2). Tingkat Kehijauan (G)}

Pada Tabel 3 tampak bahwa sebelum pemanasan $\left(105^{\circ} \mathrm{C}\right)$, produk bubuk dengan konsentasi $\mathrm{Cu}^{2+} 100 \mathrm{mg} / \mathrm{l}$ mempuyai tingkat kehijauan yang relatif tinggi dibanding konsentrasi $\mathrm{Cu}^{2+}$ yang lain, namun tidak berbeda nyata dengan dengan $\mathrm{Cu}^{2+} 150 \mathrm{mg} / \mathrm{l}$, baik sebelum maupun sesudah dipanaskan. Nilai tingkat kehijauan produk bubuk sebelum pemanasan lebih tinggi dibandingkan dengan produk sesudah pemanasan. Produk kontrol $\left(\mathrm{Cu}^{2+} 0 \mathrm{mg} / \mathrm{l}\right)$ mempunyai tingkat kehijauan yang paling rendah. Hal ini menunjukkan penambahan $\mathrm{Cu}^{2+}$ relatif dapat mempertahankan tingkat kehijauan produk yang dihasilkan, karena adanya ikatan antara $\mathrm{Cu}^{2+}$ dan turunan klorofil (feofitin) yang relatif kuat.

Perubahan tingkat kehijauan produk bubuk Cu-turunan klorofil (Cu 100 mg/l) setelah pemanasan jauh lebih rendah diban- ding bubuk $\mathrm{Zn}$-turunan klorofil daun singkong $\left(\mathrm{Zn}^{2+}\right.$ $100 \mathrm{mg} / \mathrm{l})$ hasil penelitian Alsuhendra (2004). Hasil penelitiannya menunjukkan penurunan tingkat kehijauan bubuk Zn-turunan klorofil sebesar 5.60 poin, setelah dipanaskan pada temperatur $105^{\circ} \mathrm{C}$. Hal ini berarti bahwa kadar klorofil dalam bubuk juga menurun.

Terjadinya penurunan tingkat kehijauan yang relatif besar, diduga terkait dengan rendahnya afinitas $\mathrm{Zn}$ terhadap porfirin dibanding $\mathrm{Cu}$. Dalam hubungannya dengan klorofil alami, Faboya (2006) melaporkan bahwa pada suhu sekitar $100^{\circ} \mathrm{C}$ dan $\mathrm{pH} 6$, total klorofil akan hilang paling sedikit 56\% Namun pada penelitian ini tidak dilaporkan adanya tam- bahan mineral logam tertentu, selain Mg yang secara alami memang terkandung pada klorofil tersebut.

Hasil penelitian ini menunjukkan penurunan tingkat kehijauan bubuk Cu-turunan klorofil relatif kecil, hanya sebesar 1.09 poin. $\mathrm{Hal}$ ini menunjukkan bahwa logam pengelat $\mathrm{Cu}$ relatif lebih stabil dalam mempertahankan tingkat kehijauan klorofil. $\mathrm{Hal}$ ini sesuai dengan pernyataan Cheng et al., (1982), serta Mahan dan Stump (2004), bahwa Cu mempunyai tingkat stabili- 
tas atau afinitas yang lebih tinggi untuk berikatan dengan ligan yang kaya elektron dibanding Zn.

\section{(2). Tingkat Kekuningan (Y)}

Pada Tabel 3 tampak produk bubuk dengan konsentrasi $\mathrm{Cu} 0$ ppm mempunyai tingkat kekuningan yang tertinggi yaitu sebesar 12.44. Kemudian disusul produk bubuk dengan konsentrasi $\mathrm{Cu} 100$ ppm. Pada Tabel tersebut tampak bahwa tingkat kekuningan relatif berfluktuasi seiring dengan meningkatnya konsentrasi $\mathrm{Cu}$ dalam produk bubuk. Warna kuning-hijau menunjukkan klorofil $b$ yang lebih polar, sedangkan bila berwarna biru-hijau menunjukkan klorofil $a$ yang kurang polar (Goss, 1991).

\section{Hasil Uji Proksimat dari Bubuk Cu-turunan klorofil terpilih}

Berdasarkan uji karakteristik fisiko-kimia di atas, tampak bahwa produk bubuk ekstrak klorofil daun cincau hijau yang mempunyai tingkat kehijauan, kelarutan, dan $\mathrm{pH}$ yang tinggi adalah produk ekstrak dengan konsentrasi Cu 100 ppm.

Kadar gizi (hasil uji proksimat) dan $\beta$ karoten dari bubuk tersebut tampak pada Tabel 4. Bubuk ekstrak Cu-turunan klorofil (konsentrasi $\mathrm{Cu} 100 \mathrm{ppm}$ ) mengandung protein $0.89 \%$ lemak $7.11 \%$ abu $2.63 \%$ air $6.93 \%$ serat kasar $3.31 \%$ dan $\beta$-karoten sebesar 3.38 $\mathrm{mg} / 100 \mathrm{~g}(33.8 \mathrm{mg} / \mathrm{kg})$.

Tabel 4. Kadar Zat Gizi dan Zat Non-gizi

\begin{tabular}{lc}
\multicolumn{2}{c}{ Bubuk Cu-turunan Klorofil (Cu $100 \mathrm{ppm})$} \\
\hline Parameter & Kadar \\
\hline Protein & $0.89 \%$ \\
Lemak & $7.11 \%$ \\
Abu & $2.63 \%$ \\
Air & $6.93 \%$ \\
Serat kasar & $3.31 \%$ \\
$\beta$-karoten & $33.8 \mathrm{mg} / \mathrm{kg}$ \\
Klorofil & $3986 \mathrm{mg} / \mathrm{kg}$ \\
\hline
\end{tabular}

\section{Hasil Uji Kualitatif Zat Fitokimia Bubuk Ekstrak Cu-turunan klorofil dan Klorofil Komersial}

Uji fitokimia ini bertujuan untuk mengetahui jenis-jenis zat bioaktif lain dalam bubuk klorofil yang dibuat. Hasil uji fitokimia bubuk ekstrak Cu-turunan klorofil menunjukkan bahwa bubuk ekstrak Cu-turunan klorofil mengandung 5 zat fitokimia yang dominan antara lain: alkaloid, saponin, tanin, steroid, dan glikosida (Tabel 5).
Kandungan tanin dalam bubuk Cuturunan klorofil cincau mempunyai nilai tambah tersendiri. Selain sebagai antioksidan, tanin bisa digunakan untuk membunuh bakteri baik pada Streptococcus pyogenes maupun Pasteurella multocida (in vitro) (Siswantoro, 2008).

Tabel 5. Hasil Analisis Fitokimia (Kualitatif) Bubuk Cu-turunan Klorofil $\left(\mathrm{Cu}^{2+} 100\right.$ $\mathrm{mg} / \mathrm{I}$ ) dan Bubuk Klorofil Komersial

\begin{tabular}{lc}
\hline \multicolumn{1}{c}{ Komponen } & Keterangan \\
\hline Alkaloid & $+1+$ \\
Saponin & $+1+$ \\
Tanin & $+1+$ \\
Fenolik & - \\
Flavonoid & - \\
Triterpenoid & - \\
Steroid & + H+ \\
Glikosida & + H+ \\
\hline
\end{tabular}

\begin{tabular}{llll}
\hline Keterangan: & & \\
Hasil negatif & $=$ & - \\
Hasil positif lemah & $=$ & + \\
Hasil positif kuat & $=$ & ++ \\
Hasil positif kuat sekali & $=$ & +++ \\
Hasil positif sangat kuat & $=$ & ++++
\end{tabular}

\section{KESIMPULAN}

Daun cincau (Premna oblongifolia Merr.) mempunyai kadar klorofil tertinggi dibandingkan daun lainnya (pegagan, katuk, dan murbei), sehingga daun cincau diguna- kan sebagai bahan untuk membuat bubuk $\mathrm{Cu}$ turunan klorofil.

Konsentrasi $\mathrm{Cu}$ (tembaga) yang terbaik dalam hal pembentukan bubuk Cu-turunan klorofil cincau (Premna oblongifolia Merr.) adalah 100 ppm. Penilaian ini ditinjau berdasarkan hasil uj i pH yang relatif tinggi, warna yang relatif lebih hijau, lebih terang, kelarutan tinggi. Bubuk Cu-turunan klorofil mengandung klorofil dan $\beta$-karoten masingmasing sebesar $33.8 \mathrm{mg} / \mathrm{kg}$ dan $3986 \mathrm{mg} / \mathrm{kg}$.

Hasil uji fitokimia bubuk ekstrak Cu-turunan klorofil daun cincau (Premna oblongifolia Merr.) menunjukkan bahwa bubuk ekstrak Cu-turunan klorofil mengandung 5 zat fitokimia utama yang berguna untuk peningkatan kesehatan antara lain: alkaloid, saponin, tanin, steroid, dan glikosida. 


\section{UCAPAN TERIMA KASIH}

Penulis mengucapkan terima kasih kepada Sekretariat Badan Litbang Pertanian Departemen Pertanian RI atas dana penelitian yang diberikan melalui Prog KKP3T dengan No. Kontrak: 723/ LB.620/I. 1/ 3/ 2008.

\section{DAFTAR PUSTAKA}

Alsuhendra. 2004. Daya Anti-atherosclerosis Zn-Turunan Klorofil dari Daun Singkong (Manihot esculenta Crantz) pada Kelinci Percobaan. Disertasi Doktoral Sekolah Pascasarjana, IPB, Bogor.

Bianca K. 1993. Pengaruh Penambahan $\mathrm{ZnCl}_{2}$ di Dalam Pembuatan Ekstrak Warna dari Campuran Daun Suji (Pleomele angustifolia) dan Daun Pandan (Pandanus amarylifollus Roxb.) Skripsi Sarjana Fakultas Teknologi Pertanian, IPB, Bogor.

[BPOM] Badan Pengawas Obat dan Makanan. 2001. Kebijakan Pengembangan Obat Alam/Herbal Medicine Indonesia. Badan POM, J akarta.

[BPOM] Badan Pengawas Obat dan Makanan. 2004. Keputusan Kepala Badan Pengawas Obat dan Makanan RI Nomor HK.00.05.23.3644 Tahun 2004 tentang Ketentuan Pokok Pengawasan Suplemen Makanan. Badan POM, J akarta.

Canjura FL, Watkins RH, \& Schwartz. 1999. Color improvement and metallochlorophyll complexes in continuous flow aseptically processed peas. J II of Food Sci. 64 (6), 987-990.

Cheng KL, Ueno K, \& Imamura T. 1982. Handbook of Organic Analytical Reagents. CRC Press, Boca Raton, Florida.

Faboya 00. 2006. Chlorophyll changes in some geen leafy vegetables during cooking. J. of the Science of Food and Agiculture. 36(8), 740-744.

Ferruzzi MG, Bohm V, Courtney PD. \& Schwartz SJ. 2006. Antioxidant and Antimutagenic Activity of Dietary Chlorophyll Derivatives Determined by Radical Scavenging and Bacterial Reverse
Mutagenesis Assays. J.Food Science 67: 2589-2595.

Goss J. 1991. Pigments in Vegetables: Chlophylls and Carotenoids. Van Nostrand Reinhold, New York.

Kotani M, Yamauchi N, Ueda Y, Imahori Y, \& Chachin K. 1999. Chlorophyll Degadation in Boiled Broccoli Florets during Storage in the Light. Food Science and Technology Research. 5(1), pp. 35-38.

LaBorde LF \& von Elbe JH. 1994. Chlorophyll degadation and zinc complex formation with chlorophyll derivatives in heated geen vegetables. J.Agic. Food Chem. 42(5), 1100-1103.

Mahmud M. 1994. Pemurnian Klorofil Daun Suj $i$ (Pleomele angustifolia N.E.Brown). Skripsi Sarjana Jurusan Kimia, Fakultas MIPA, IPB, Bogor.

Mahan LK, Stump SE. 2004. Food, Nutrition, \& Diet Therapy. Ed ke-2. Saunders, Philadelphia.

Marquez UML, Barros RMC, Sinnecker P. 2005. Antioxidant activity of chlorophylls and their derivates. Food Research International 38, 885-891.

Prangdimurti E. 2007. Kapasitas Antioksidan dan Daya Hipokolesterolemik Ekstrak Daun Suji (Pleomele angustifolia N.E. Brown). Disertasi Doktoral Sekolah Pascasarjana, IPB, Bogor.

Siswantoro D. 2008. Kajian Aktivitas Tanin dengan Penisilin terhadap Bakteri Streptococcus Pyogenes dan Pasteurella Multocida secara in vitro. Dalam http:// adln. lib. unair. ac.id.

Von Elbe JH, Huang AS, Attoe EL, \& Nank WK. 1986. Pigmen composition and color of conventional and Veri-Geen canned. J. Agic. Food Chem. 34(1), 52-54. 
J urnal Gizi dan Pangan, Maret 2009 4(1): 13 - 19 